\title{
Climate Change and Tritrophic Interactions: Will Modifications to Greenhouse Gas Emissions Increase the Vulnerability of Herbivorous Insects to Natural Enemies?
}

\author{
ANTOINE BOULLIS, FREDERIC FRANCIS, AND FRANC’OIS J. VERHEGGEN ${ }^{1}$ \\ Gembloux Agro-Bio Tech, University of Liège, Entomologie fonctionnelle et évolutive, Passage des déportés, 2-5030 Gembloux, Belgium
}

\section{Environ. Entomol. 1-10 (2015); DOI: 10.1093/ee/nvu019}

\begin{abstract}
Insects are highly dependent on odor cues released into the environment to locate conspecifics or food sources. This mechanism is particularly important for insect predators that rely on kairomones released by their prey to detect them. In the context of climate change and, more specifically, modifications in the gas composition of the atmosphere, chemical communication-mediating interactions between phytophagous insect pests, their host plants, and their natural enemies is likely to be impacted. Several reports have indicated that modifications to plants caused by elevated carbon dioxide and ozone concentrations might indirectly affect insect herbivores, with community-level modifications to this group potentially having an indirect influence on higher trophic levels. The vulnerability of agricultural insect pests toward their natural enemies under elevated greenhouse gases concentrations has been frequently reported, but conflicting results have been obtained. This literature review shows that the higher levels of carbon dioxide, as predicted for the coming century, do not enhance the abundance or efficiency of natural enemies to locate hosts or prey in most published studies. Increased ozone levels lead to modifications in herbivore-induced volatile organic compounds (VOCs) released by damaged plants, which may impact the attractiveness of these herbivores to the third trophic level. Furthermore, other oxidative gases (such as $\mathrm{SO}_{2}$ and $\mathrm{NO}_{2}$ ) tend to reduce the abundance of natural enemies. The impact of changes in atmospheric gas emissions on plant-insect and insect-insect chemical communication has been under-documented, despite the significance of these mechanisms in tritrophic interactions. We conclude by suggesting some further prospects on this topic of research yet to be investigated.
\end{abstract}

RÉSUMÉ Chez les insectes, les comportements de recherche de nourriture ou de partenaires reposent sur leur capacité à percevoir des signaux chimiques présents dans l'environnement : c'est le cas chez les insectes parasitoïdes et prédateurs qui utilisent les kairomones émises par leurs hôtes/proies pour les localiser. Dans un contexte de changements climatiques, et plus précisément de modifications des concentrations atmosphériques en gaz à effet de serre, la communication chimique entre insectes phytophages, plantes hôtes et ennemis naturels pourrait être impactée. En effet, plusieurs études ont démontré que des modifications chez les plantes dues à l'augmentation des concentrations en dioxyde de carbone et ozone pouvaient impacter indirectement les insectes phytophages, ainsi que les niveaux trophiques supérieurs. Plusieurs études se sont intéressées à l'effet des changements gazeux sur la vulnérabilité des insectes phytophages vis-à-vis de leurs ennemis naturels. Leurs résultats sont dans l'ensemble variables. Cette synthèse bibliographique indique que l'augmentation de la concentration en $\mathrm{CO}_{2}$ n'augmente généralement pas l'efficacité ou l'abondance des ennemis naturels. L'augmentation $\mathrm{d}^{\prime} \mathrm{O}_{3}$ va induire des modifications dans la production de métabolites secondaires produits par les plantes, ce qui pourrait avoir un impact sur l'attractivité des ennemis naturels. Laugmentation des concentrations d'autres gaz $\left(\mathrm{SO}_{2}\right.$ et $\left.\mathrm{NO}_{2}\right)$ réduiraient l'abondance des ennemis naturels. En outre, l'impact des changements gazeux sur les communications chimiques plantes-insectes et insectes-insectes sont sous-documentés, malgré la prévalence de ces mécanismes au sein des interactions tri-trophiques. Les recherches futures devraient s'intéresser à ces mécanismes régissant l'efficacité des ennemis naturels, tout en tenant compte de l'intégralité du réseau trophique.

KEY WORDS climate change, $\mathrm{CO}_{2}$, ozone, natural enemy, chemical ecology

\section{Climate Change and Greenhouse Gas Emissions}

Since the beginning of the industrial era (1850s), the concentration of greenhouse gases has increased in the atmosphere, inducing a wide range of environmental

\footnotetext{
${ }^{1}$ Corresponding author, email: fverheggen@ulg.ac.be.
}

changes (Intergovernmental Panel on Climate Change [IPCC] 2013). Such changes include a rise in the Earth's surface temperature, sea level, the number of natural disasters, and precipitation. These phenomena could lead to the reduction of agricultural production, a loss of specialist species, and an increase in disease vector populations, including insects. For example, the 
atmospheric content of carbon dioxide $\left(\mathrm{CO}_{2}\right)$, which is considered to be chiefly responsible of the greenhouse effect (IPCC 2013), increased from $\sim 310 \mathrm{ppm}$ in 1950 to $\sim 400 \mathrm{ppm}$ in 2011 . This concentration is estimated to reach levels of 421-936 ppm by the end of the twenty-first century, according to forecasting models, depending on the magnitude of future human activities (IPCC 2013). The quantities of other gases, such as tropospheric ozone $\left(\mathrm{O}_{3}\right)$ and nitrogen dioxide $\left(\mathrm{NO}_{2}\right)$, which are considered to be greenhouse gases and toxic pollutants for biological organisms, have also increased in the lower atmosphere because of human activity, and are responsible for modifications to agricultural and natural ecosystems (Karnosky et al. 2007, Meleux et al. 2007).

Increased greenhouse gas concentrations in the atmosphere lead to physiological changes in plants. This topic has been extensively documented over the past $20 \mathrm{yr}$, especially with respect to modifications caused by the greenhouse gases of most concern, namely, $\mathrm{CO}_{2}$ and $\mathrm{O}_{3}$ (e.g., Ceulemans et al. 1999, Ashmore 2005, Lindroth 2010). Observed direct effects on plant include an increased C:N ratio and increased growth rates (DeLucia et al. 2012), along with modifications in the production of plant metabolites (Pinto et al. 2008). These direct effects on plants may also have indirect effects on organisms in the higher trophic systems, through the modification of trophic cascades (BidartBouzat and Imeh-Nathaniel 2008). Consequently, interactions between plants and insect herbivores have received greater attention compared with interactions between phytophagous insects and their natural enemies (Coviella and Trumble 1999, Whittaker 1999, Holopainen 2002, Lindroth 2010, DeLucia et al. 2012). Yet, the preliminary results remain inconclusive regarding the extent to which modifications in the emissions of greenhouse gases are likely to influence the efficiency of beneficial insects at controlling phytophagous pests. In this review, we summarize the findings from experimental studies that examined the influence of greenhouse gas emissions on interactions between plants, insect herbivores, and their natural enemies.

\section{Atmospheric Changes Affect Plant-Herbivore Interactions}

The impact of elevated greenhouse gas concentrations on the performance of herbivores has been well studied and reviewed in previous publications (Bezemer and Jones 1998, Coviella and Trumble 1999, Whittaker 1999, Stiling and Cornelissen 2007, Lindroth 2010). $\mathrm{CO}_{2}$ is also the most studied greenhouse gas in climate change research. Higher levels of $\mathrm{CO}_{2}$ in the atmosphere impact plants by increasing their tissue $\mathrm{C}: \mathrm{N}$ ratios, as well as by increasing their growth rates but lowering their nutritional value (DeLucia et al. 2012). In addition, higher levels of $\mathrm{O}_{3}$ in the troposphere also have an important effect on plants, which has been documented in detail (Ashmore 2005, BidartBouzat and Imeh-Nathaniel 2008, Pinto et al. 2010). $\mathrm{O}_{3}$ principally modifies the emission of secondary metabolites emitted by plants, including terpenoids and phenols, and their perception by other organisms (Lindroth 2010, Pinto et al. 2010).

Consequently, these modifications to plants are likely to affect insect herbivores by altering various processes, such as their development rates, food consumption, and digestibility (Bezemer and Jones 1998). However, these observations are based on several groups of phytophagous insects. Consequently, it is not possible to draw general conclusions because the results are highly dependent on insect feeding habits (Bezemer and Jones 1998) or on certain plants and insect species (Whittaker 1999). Indeed, different responses may be obtained for different insect guilds (leaf-chewer, leafminer, and sap-feeder) feeding on $\mathrm{C}_{3}$ versus $\mathrm{C}_{4}$ plants (Bezemer and Jones 1998, Coviella and Trumble 1999).

Most publications document an increase in the foliage consumption of leaf-eaters under elevated $\mathrm{CO}_{2}$ concentrations (e.g., Bezemer and Jones 1998). The increase in development time is another strategy used to counter lower nutrient concentrations of plant tissues (Coviella and Trumble 1999, Stiling and Cornelissen 2007). The effects of increased $\mathrm{CO}_{2}$ concentrations on sap-feeders vary according to the type of plant tissue that the insect is feeding on (Bezemer and Jones 1998). A review by Holopainen (2002) highlights contrasting results for aphid performance when reared on plants under elevated $\mathrm{CO}_{2}$ conditions, with studies showing increased, decreased, or unchanged performance compared with ambient $\mathrm{CO}_{2}$ levels. These variable results may be related to the specificity of the plant-insect interactions or to differences in environmental and experimental factors (Bezemer and Jones 1998). In general, long-term rearing under elevated $\mathrm{CO}_{2}$ conditions reduces the development time of aphids (Bezemer and Jones 1998).

$\mathrm{O}_{3}$ has also an important impact on plant-insect interactions. This phytotoxic gas modifies the biosynthetic pathway of important secondary metabolites (Holopainen 2002), leading to changes in plant volatile cues, and subsequently affecting how phytophagous insects locate host plants (Pinto et al. 2010). Moreover, secondary plant metabolites are also used as synomones by the natural enemies to find phytophagous insects (Vet and Dicke 1992). Thus, these plant metabolites may be affected by modifications to atmospheric $\mathrm{O}_{3}$ concentrations (Lindroth 2010, Bidart-Bouzat and Imeh-Nathaniel 2008, Pinto et al. 2010). For example, phytophagous insect oviposition is principally linked to chemical cues perceived by laying females (Bruce et al. 2005), and elevated $\mathrm{O}_{3}$ concentrations cause a reduction in the oviposition rates of the leaf beetle Plagiodera versicolora (Laicharting) on cottonwood (Jones and Coleman 1988). Furthermore, aphids respond differently to elevated $\mathrm{O}_{3}$, leading to an increase or decrease in their performance, depending on the length of time that a plant has been exposed to elevated $\mathrm{O}_{3}$ or the age of the host plant (Jackson 1995, Holopainen 2002).

The impact of other gases on plant-insect interactions has also been studied, but to a lesser extent. A recent meta-analysis (Zvereva and Kozlov 2010) of 134 studies showed the overall effect of air pollutant on 
herbivorous arthropods. Different pollutant categories do not affect phytophagous insect performance, except in rare cases where they may increase it. Furthermore, the performance of aphids in polluted areas primarily depends on the overall concentration of pollutants rather than on the presence of specific ones (Jackson 1995).

\section{Atmospheric Changes Affect Interactions with Natural Enemies}

In natural and agricultural ecosystems, phytophagous insects are considered to be the cornerstone of the tritrophic relationship among host plants-insect herbivores-natural enemies (Walker and Jones 2001). To predict the impact of modifications to herbivore communities on the whole system, it is important to consider the mutual interactions of all three trophic levels. Under natural conditions, the expansion of phytophagous species is highly dependent on resource availability, but it is also regulated by the activity of higher trophic levels.

Carbon Dioxide. The augmentation of atmospheric $\mathrm{CO}_{2}$ is responsible for several modifications in plant-insect interactions, including the food consumption and development rates of phytophagous insect pests, which might increase, decrease, or remain unchanged. Therefore, different direct and indirect fitness traits of natural enemies are susceptible to modification via cascade effects. Here, again, the responses in top-down interactions are highly variable (Table 1). Moreover, variations in additional abiotic and biotic parameters, in addition to stochasticity, contribute to these variations. For example, Sun et al. (2011) showed that the development time of the aphid parasitoid Lysiphlebia japonica (Ashmead) Ashmead significantly decreases under elevated $\mathrm{CO}_{2}$, but only for two of the three tested genotypes. Vuorinen et al. (2004) observed that the plant genotype has similar impacts on the Lepidoptera parasitoid Cotesia plutellae (Kurdjumov). Another study investigating the performance of the parasitoid Aphidius picipes (Nees) feeding on the aphid Sitobion avenae (F.) showed that the parasitism rate (\% of parasitized individuals) increased under elevated $\mathrm{CO}_{2}$ concentrations (Chen et al. 2007), but that elevated $\mathrm{CO}_{2}$ concentrations tended to decrease the abundance of newly emerged adult parasitoids. Therefore, under elevated $\mathrm{CO}_{2}$ concentrations, the overall fitness of a given species will be positively or negatively influenced according to its life history traits. For instance, Bezemer et al. (1998) found no difference in the parasitism rate of the parasitoid Aphidius matricariae Haliday between ambient and elevated $\mathrm{CO}_{2}$ treatments. Furthermore, an increase in atmospheric $\mathrm{CO}_{2}$ concentration did not influence the preference and efficiency of the aphid parasitoid Diaretiella rapae (McIntosh) (Stacey and Fellowes 2002). In contrast, Klaiber et al. (2013) showed a decrease in the efficiency of $D$. rapae under elevated $\mathrm{CO}_{2}$ concentrations compared with ambient $\mathrm{CO}_{2}$ concentrations, with $\sim 50 \%$ reduction in parasitized hosts number and short-lived emerging adults. Elevated $\mathrm{CO}_{2}$ also impairs the performance of the parasitoid Cotesia melanoscela (Ratzeburg), with an observed increase of C. melanoscela larval and pupal mortality (Roth and Lindroth 1995). Holton et al. (2003) found that elevated $\mathrm{CO}_{2}$ concentrations had no impact on the performance of Compsilura concinnata (Meigen). Similarly, the mortality of different leafminer species associated with parasitism under elevated $\mathrm{CO}_{2}$ was not significantly different from that observed under ambient $\mathrm{CO}_{2}$ conditions (Stiling et al. 1999). All of these cited studies demonstrate the major variability in parasitoid performance under elevated $\mathrm{CO}_{2}$ conditions.

Unlike parasitoids, fewer studies have focused on how elevated $\mathrm{CO}_{2}$ impacts the efficiency of predators (Table 1). The coccinellid family is the major insect group considered in this research topic. Here, again, the response of higher trophic levels to elevated concentrations of $\mathrm{CO}_{2}$ appears highly variable. Chen et al. $(2005,2007)$ investigated the diet preference of Harmonia axyridis (Pallas) in food choice experiments. The two studies by the authors showed that $H$. axyridis prefers to consume aphids grown under elevated $\mathrm{CO}_{2}$ concentrations rather than under ambient $\mathrm{CO}_{2}$ conditions. However, despite this preference, the performance of the predator (efficacy to control aphids) was not affected under high concentration of $\mathrm{CO}_{2}$. Finally, the time needed for larval development time was significantly shorter or remained unchanged under modified $\mathrm{CO}_{2}$ environments (Chen et al. 2005, 2007). Concerning the searching behavior of predators, Vuorinen et al. (2004) showed that, unlike plants grown under ambient $\mathrm{CO}_{2}$, the spined soldier bug Podisus maculiventris (Say) does not discriminate herbivore-damaged plants from intact plants under elevated $\mathrm{CO}_{2}$, regardless of host plant cultivar. Other results tend to show similar consumption rates under both ambient and elevated $\mathrm{CO}_{2}$ conditions for Hippodamia convergens GuérinMéneville (Stacey and Fellowes 2002), regardless of the aphid species being predated on. Two other studies conducted in the early 2000 s investigated the impact of natural enemies on the population dynamics of tree aphid species. These studies found that the density of natural enemies (essentially lady beetles and parasitoids) tended to increase in elevated $\mathrm{CO}_{2}$ treatments, but only on some sample dates (Percy et al. 2002, Awmack et al. 2004). However, the relative effect on the asynchrony between aphid prey and their enemies made it difficult to determine whether the performance of natural enemies was enhanced.

It is essential to note that the major variation observed in the results of these studies is caused by more than just species-specific relationships. Experimental conditions may have also influenced the results. For instance, Stacey and Fellowes (2002) and Klaiber et al. (2013) studied the same host-parasitoid species complex, but obtained different results. The former study found that increased $\mathrm{CO}_{2}$ did not affect the performance of $D$. rapae, whereas the latter study found a reduction in efficiency. There were several noticeable differences in the methods used by each study. For example, the difference in the $\mathrm{CO}_{2}$ concentration between the ambient and elevated treatments was 


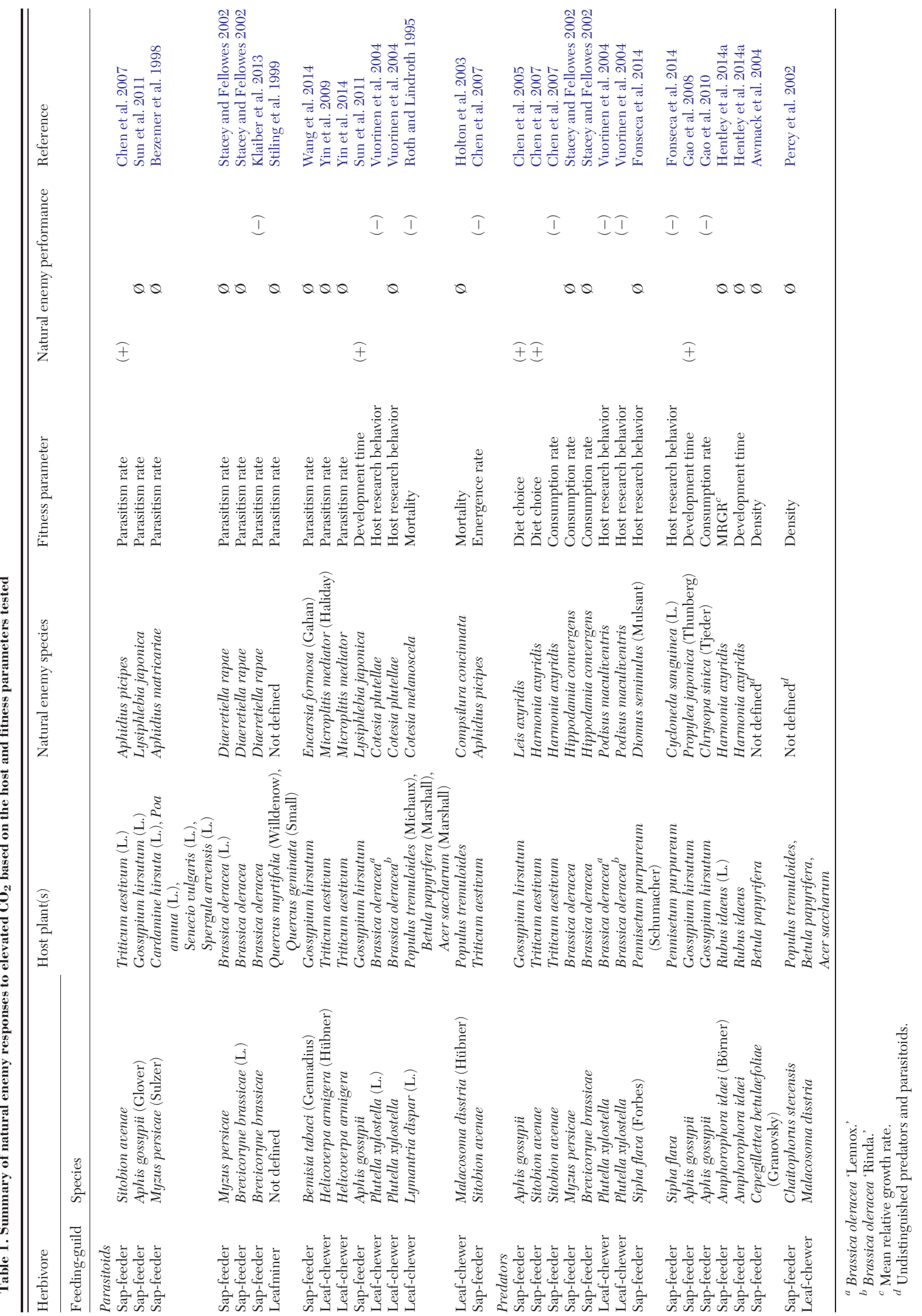


lower in the study by Stacey and Fellowes (2002) compared with Klaiber et al. (2013). Also, a lower modification in $\mathrm{CO}_{2}$ concentration could lead to a lower impact on parasitoid efficiency. In addition, selection of the parameter for assessment in a study is fundamental because different traits could produce different responses under elevated $\mathrm{CO}_{2}$ conditions. For instance, Chen et al. (2007) concluded that the impact of increased $\mathrm{CO}_{2}$ on parasitoid performance differs according to the parameter studied: parasitism rate increased under elevated $\mathrm{CO}_{2}$ treatments, whereas emergence rate clearly decreased. Similar conclusions were reached by Sun et al. (2011), who found that elevated $\mathrm{CO}_{2}$ does not influence the parasitism rate of $L$. japonica, but it does reduce the development time. To estimate as realistically as possible the impact of elevated $\mathrm{CO}_{2}$, it is important to consider traits that are directly linked to fitness (such as reproductive or parasitism rates, and survivorship). Consequently, it is not possible to provide general rules about the impact of elevated $\mathrm{CO}_{2}$ concentrations on top-down relationships.

Ozone. Compared with $\mathrm{CO}_{2}$, fewer published studies address the impact of $\mathrm{O}_{3}$ on interactions involving higher trophic levels. All of these studies have principally focused on parasitoids rather than on predators. Parasitoids, which are considered to be more specialists than predators, seem to be more able to detect the presence of herbivore-induced damage to plants through the perception of secondary metabolites released into the environment by the plant (Holopainen et al. 2013). $\mathrm{O}_{3}$ is more responsible for modifications to plant secondary metabolites and foliar composition than most other greenhouse gases, including $\mathrm{CO}_{2}$. Holton et al. (2003) found that elevated $\mathrm{O}_{3}$ concentrations may reduce the fitness of the parasitoid C. concinnata by reducing its survivorship, which is primarily due to the decrease in the nutritional quality of its herbivore host. In addition, Gate et al. (1995) indicated that $\mathrm{O}_{3}$ could have both direct effects on parasitoids by altering their olfactory receptors and indirect effects by reacting with kairomones and synomones in the environment. Specifically, Gate et al. (1995) found that the searching behavior of the parasitoid Asobara tabida (Nees) changed under elevated $\mathrm{O}_{3}$ concentrations compared with the control treatment. Furthermore, A. tabida exhibited lower rates of parasitism under $\mathrm{O}_{3}$ fumigation compared with the nonfumigated treatment. Pinto et al. (2007a,b, 2008) found that the parasitoid C. plutellae and the predatory mite Phytoseiulus persimilis Athias-Henriot are able to discriminate plants damaged by their prey herbivore under both ambient and elevated $\mathrm{O}_{3}$ concentrations. However, the two enemies of the herbivore preferred damaged plants grown under ambient $\mathrm{O}_{3}$ concentrations compared with those cultivated under elevated $\mathrm{O}_{3}$. In a field experiment by Pinto et al. (2008) designed to replicate the natural ecosystem as much as possible, it was found that neither the searching behavior nor the parasitism rate of the parasitoid C. plutellae were disturbed by $\mathrm{O}_{3}$ fumigation. Finally, Awmack et al. (2004) and Percy et al. (2002) showed that $\mathrm{O}_{3}$ fumigation had respectively no impact or led to a major decline in the abundance of natural enemy communities in forests. These contrasting results obtained at the same study site (Aspen FACE, Wisconsin) illustrate the complex effect of increased greenhouse gas concentrations on trophic interactions, and demonstrate the idiosyncratic characteristics of natural enemy responses.

Other Air Pollutants. Initial studies conducted during the 1980s assessed the impact of pollution by various factories on pest control by natural enemies (Villemant 1981, Heliövaara and Väisäsen 1986). The results showed that air pollutants from heavy metals did not have any influence on the performance of parasitoid species. More recently, a meta-analysis on the effect of air pollutants on parasitoids exposed to different pollutants in $\sim 40$ biological systems revealed that beneficial effects only occurred in $7.6 \%$ of the reviewed cases (Butler et al. 2009). The remaining 92.4\% were equally distributed between no effect and deleterious effects (46.2\% each). Zvereva and Kozlov (2000, 2006) also studied the effect of the proximity of heavy smelter (source of heavy metals and sulfur dioxide) on topdown trophic interactions. The authors found that a higher density of herbivorous insects, such as leaf beetles and Lepidoptera, were present in polluted areas compared with clean zones, which was certainly due to the low abundance of natural enemies. Moreover, the percentage of herbivore mortality owing to predation and parasitism was generally lower in polluted areas. Gate et al. (1995) found that the parasitism rate and search efficiency performance of the parasitoid A. tabida was not affected by fumigations of sulfur dioxide $\left(\mathrm{SO}_{2}\right)$ and $\mathrm{NO}_{2}$ at $100 \mathrm{nl} \cdot$ liter ${ }^{-1}$ compared with filtered air.

In general terms, parasitism rate of several Hymenoptera and Diptera species is not strongly modified by elevated $\mathrm{CO}_{2}$ concentration (Table 1), whereas elevated $\mathrm{O}_{3}$ levels negatively affect this parameter. Host-searching behavior of parasitoids is negatively impacted by increases in $\mathrm{CO}_{2}$ and $\mathrm{O}_{3}$ atmospheric levels, with herbivores being less easily localizable and likely to be less controlled. Predator prey-searching behavior is also negatively altered, as their consumption rate under high level of $\mathrm{CO}_{2}$ is reduced. On the other hand, increases in greenhouse gas concentrations reduce the development time of the larval and pupal stage of natural enemies of insect herbivores.

\section{Atmospheric Changes Affect Tritrophic Chemical Signaling}

The efficiency of predators and parasitoids has been generally estimated through the impact of elevated greenhouse gas atmospheric concentrations on their life history traits, and is directly or indirectly related to individual fitness. However, these characteristics may alter among interactions, species, and even individuals owing to variations in environmental conditions, stochasticity, and genetic plasticity, leading to major variability in the effect of increased greenhouse gas emissions on the efficiency of natural enemies. Yet, changes in these traits reflect the consequences of 
modifications to mechanisms that usually govern stability in top-down trophic interactions. One major mechanism involved in organism interactions is intra- and interspecific chemical communication. Changes in chemical communication may certainly lead to the modifications observed in the studies reviewed here.

Semiochemicals drive a range of ecological interactions, including top-down trophic interactions. Specifically, natural enemies use kairomones produced by their prey, as well as synomones produced by their prey host plants, to locate the host or prey. Specialist natural enemies, which only respond to the chemicals emitted or induced by a certain group of organisms (species, genera, etc.), are not only able to detect chemical cues but also depend on these cues to maintain their reproductive fitness (Dicke 2000). Modifications in the emission and perception of these cues could lead to a decline of specialists, whereas generalists could benefit from the situation. Perturbations in greenhouse gas concentrations could cause a modified behavioral response by receiver organisms; however, studies on this topic remain limited.

Plant Secondary Metabolites. Damaged plants release several semiochemicals into the environment when they are damaged by herbivorous insects. Such chemicals include green leaf volatiles and terpenoids, which are involved in the attraction of natural enemies. For example, aphid-induced plant signaling may act as synomones, guiding natural enemies to the host or prey, such as for the parasitoid wasp Aphidius ervi Haliday, which is able to detect aphid-damaged plants from which the aphids and aphid products have been removed (Pickett and Glinwood 2007). In natural ecosystems, where many plant species coexist, the ability of predators and parasitoids to discriminate signals is based either on the perception of taxonomically specific compounds, or on specificity of the semiochemical ratio being perceived (Bruce et al. 2005, Webster 2012). For example, glucosinolate-derived compounds are secondary metabolites chemicals emitted in constitutive blends of plants from the family Brassicaceae. These compounds are released in higher quantities under herbivores feeding, which attract specialized natural enemies (Blande et al. 2004). Under elevated $\mathrm{CO}_{2}$ conditions, the release rates of glucosinolate-derived chemicals is increased (Bidart-Bouzat and Imeh-Nathaniel 2008), which could lead to an enhanced attraction of natural enemies. On the other hand, modifications to the ratios and the dilution of herbivore-induced volatiles due to degradation by air pollutants could disorientate natural enemies (Webster et al. 2008, Holopainen et al. 2013). Pinto et al. (2007a, b) showed that the ability of parasitoid and predator species to locate host plants based on the perception of secondary plant metabolites was minimally affected under elevated $\mathrm{O}_{3}$ conditions. The only difference was that the enemies exhibited a preference for plants grown under ambient $\mathrm{O}_{3}$ concentrations compared with elevated concentrations. $\mathrm{O}_{3}$ remains the main pollutant that induces a decrease in the capacity for parasitoids to locate herbivores by means of their host plants (Gate et al. 1995, Pinto et al. 2007a, b) compared with other pollutants, such as $\mathrm{CO}_{2}, \mathrm{NO}_{2}$, or $\mathrm{SO}_{2}$, which have a lower influence on the degradation of plant volatile organic compounds. Under modified atmospheric conditions, changes in plant semiochemical profiles may finally lead to a reduction of host recognition by herbivores and natural enemies. Specialist arthropods, which relate more on accurate signals than generalist ones (Harvey et al. 2005), might be the more affected ones by these changes.

Phytophagous Insect Pheromones. Natural enemies have developed the capacity to eavesdrop the intraspecific signals used in chemical communication by behaviorally responding to herbivorous insect pheromone compounds. Many aphid species produce the sesquiterpene $(\mathrm{E})-\beta$-farnesene $(\mathrm{E} \beta \mathrm{F})$ as the main component of an alarm pheromone (Francis et al. 2005a). Predated individuals release this signal through their cornicles. Natural aphid enemies with a long coevolutionary history may develop an affinity with $\mathrm{E} \beta \mathrm{F}$ and use it to detect the presence of aphidious prey (Francis et al. 2005b, Verheggen et al. 2007, 2008).

Changes to atmospheric air pollutant concentrations may perturb chemical communication in both intraand interspecific interactions. Four key publications have focused on the impact of elevated $\mathrm{CO}_{2}$ and $\mathrm{O}_{3}$ concentrations on the perception of $\mathrm{E} \beta \mathrm{F}$ by conspecifics (Awmack et al. 1997, Mondor et al. 2004, Sun et al. 2010, Hentley et al. 2014b). Awmack et al. (1997) showed that Aulacorthum solani Kaltenbach individuals were less sensitive to the alarm pheromone (less production and perception) when reared for 4 mo under elevated $\mathrm{CO}_{2}$ concentrations compared with those from ambient $\mathrm{CO}_{2}$ concentrations. Supporting previous results, aphid $S$. avenae individuals grown under elevated $\mathrm{CO}_{2}$ did not respond to $\mathrm{E} \beta \mathrm{F}$, as well as those from the ambient $\mathrm{CO}_{2}$ treatment (Sun et al. 2010). In the tree aphid species Chaitophorus stevensis Sanborn, elevated $\mathrm{CO}_{2}$ and $\mathrm{O}_{3}$ had an antagonistic effect on aphid dispersion (Mondor et al. 2004). $\mathrm{CO}_{2}$ reduce the dispersal response to the alarm pheromone, whereas $\mathrm{O}_{3}$ enhance the alarm pheromone response. Moreover, interaction between $\mathrm{CO}_{2}$ and $\mathrm{O}_{3}$ did not cause any modification to dispersal response of aphids to their alarm pheromone. These results were recently supported: the raspberry aphids Amphorophora idaei (Börner) are less sensitive to conspecific alarm signaling or to predation pressure when plants, aphids, or both are raised under elevated $\mathrm{CO}_{2}$ concentration compared with control treatment (Hentley et al. 2014b).

\section{Future Prospects}

Several above-cited publications demonstrate the impact of modifications of plants chemistry on the efficiency of natural enemies to locate and feed on insect herbivores. Indeed, phytochemistry is of prevailing importance for the insect herbivore and their natural enemies in terms of development and host location, 


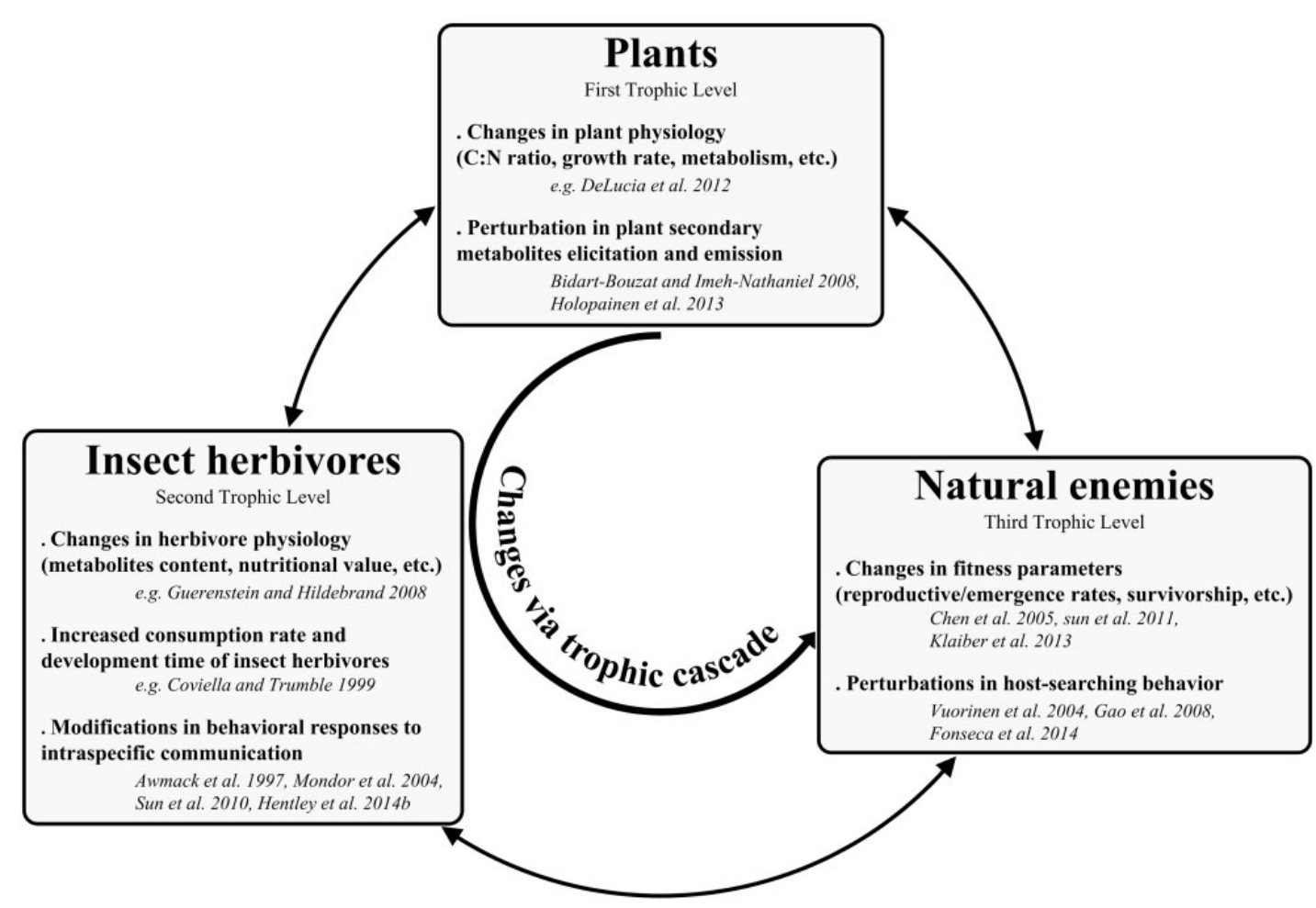

Fig. 1. Impacts of elevated atmospheric greenhouse gas concentrations on the three different trophic levels, affecting their ecological interactions via cascade effects.

respectively. As for biotic parameters, environmental factors are able to modify plant metabolism implicated in both primary (e.g., plant respiration or growth) and secondary functions (production of secondary metabolites). To better understand mechanisms underlying natural enemies' efficiency in a context of climate change, physiological modifications in plants susceptible to alter performances of insect herbivores and natural enemies (such as perturbation in the biosynthesis of secondary metabolites) have to be highlighted (Fig. 1). For example, glucosinolates and their breakdown products are characteristically emitted by Brassica sp. plants and are of great importance in multitrophic signaling, considered as toxic for generalist insects, but also as location cues for specialist phytophagous arthropods. These compounds are present in lower quantities in plants raised under elevated $\mathrm{CO}_{2}$ concentrations and may impact recruitment of beneficial insects toward infestation sites (Klaiber et al. 2013). Moreover, qualitative and quantitative compositions of phenolic chemicals, considered as ubiquitous secondary compounds involved in defenses against herbivores, are modified in plants raised under elevated atmospheric gas concentrations (Hartley et al. 2000, Holton et al. 2003). The composition of a phenolic diet likely influences and physiological traits of both the insect herbivore and its natural enemies (Roth et al. 1997), highlighting the potential cascade effect of plant changes induced by modifications in atmospheric gas composition (Fig. 1). As for other factors, elevated $\mathrm{CO}_{2}$ concentration also induces changes in nutritional value of plant toward phytophagous insects (Yin et al. 2014); gossypol content in plants has indirect effects on different biological parameters of feeding aphids (Gao et al. 2008). Fatty acid content of aphids grown under elevated $\mathrm{CO}_{2}$ concentrations is lowered, impacting indirectly the third trophic level: predatory insects feeding on these aphids also have decreased content of free fatty acids (Gao et al. 2008). Moreover, a decrease in plant protein content may be reflected on herbivore protein content (Bezemer and Jones 1998, Guerenstein and Hildebrand 2008), decreasing their nutritional value for natural enemies, and thus reducing their fitness (Chen et al. 2005). Furthermore, modifications in plants can directly perturb the defense capabilities of herbivores toward their natural enemies, especially parasitoids (Yin et al. 2014).

All plant metabolic mechanisms underlying the above-cited examples are still poorly studied in the context of greenhouse gas changes, but deserve more attention to better understand modifications occurring in plants that impact higher trophic levels. As a general example, biosynthetic pathways in insects that lead to the production of pheromonal compounds are at the moment under-studied, as is the case of aphid alarm pheromone, for which we have limited knowledge of the exact biosynthetic pathways, although its production should be similar as that observed for other isoprenoids in plants and other herbivores (Vandermoten et al. 2012). Changes in related biogenic precursor and 
biosynthetic pathways may affect directly the synthesis of terpenoids in aphids, and, as a consequence, may affect natural enemies that use this pheromone as a kairomone to locate their prey. For example, to better understand why the behavioral mechanisms elicited by alarm stimuli in aphids are less expressed under elevated $\mathrm{CO}_{2}$ concentrations, identification of bioprecursors and related pathways may be one of the major issues for future research. Indeed, protein contents (including enzymes) in plants are modified under elevated greenhouse gas concentrations and this could be linked to modifications in the chemical compounds released by aphids.

As seen above, an increase in atmospheric greenhouse gas concentrations may lead to modifications in the interactions between herbivorous insects and their natural enemies. Unfortunately, the efficiency of beneficial arthropods under elevated greenhouse gas concentrations remains unclear because of the speciesspecific characteristics of their relationship with phytophagous insects. In most of cases, $\mathrm{CO}_{2}$ is not advantageous to natural enemies, with only $16 \%$ of the published studies showing a benefit to natural enemy efficiency, whereas $30 \%$ of studies indicated deleterious effects (54\% indicating no effect). $\mathrm{O}_{3}$ and other oxidative gases, mostly studied in parasitoid research behavior, have a general negative effect on natural enemies by degrading volatile organic compounds emitted by plants, which play an essential role in their host- or prey-searching behavior. Atmospheric gases may influence olfactory perception in insect natural enemies, but this remains to be understood. On the other hand, some studies showed a positive or null effect on natural enemy efficiency, demonstrating the major variability in these results. Studies on the synergy between gases and their impact on natural enemy efficiency are required because of potential differences in gas effects when these gases are studied separately or together.

Finally, because modifications in greenhouse gas concentrations may directly affect higher trophic levels by modifying the behavior of predators and parasitoids, or indirectly by altering physiological or, even, behavioral traits in host plants and herbivorous insects, it is important to evaluate the complete trophic system, and not only top-down relationships, because modifications to plants may have direct or indirect impacts on the natural enemies of herbivores.

\section{Acknowledgments}

A.B. was financially supported by a $\mathrm{PhD}$ grant from the Fonds pour la Formation à la Recherche dans l'Industrie et l'Agriculture (FRIA), Belgium.

\section{References Cited}

Ashmore, M. R. 2005. Assessing the future global impacts of ozone on vegetation. Plant Cell Environ. 28: 949-964.

Awmack, C. S., C. M. Woodcock, and R. Harrington. 1997. Climate change may increase vulnerability of aphids to natural enemies. Ecol. Entomol. 22: 366-368.
Awmack, C. S., R. Harrington, and R. L. Lindroth. 2004. Aphid individual performance may not predict population responses to elevated $\mathrm{CO}_{2}$ or $\mathrm{O}_{3}$. Glob. Change Biol. 10: $1414-1423$.

Bezemer, T. M., and T. H. Jones. 1998. Plant-insect herbivore interactions in elevated atmospheric $\mathrm{CO}_{2}$ : quantitative analyses and guild effects. Oikos 82: 212-222.

Bezemer, T. M., T. H. Jones, and K. J. Knight. 1998. Long-term effects of elevated $\mathrm{CO}_{2}$ and temperature on populations of the peach potato aphid Myzus persicae and its parasitoid Aphidius matricariae. Oecologia 116: $128-135$.

Bidart-Bouzat, M. G., and A. Imeh-Nathaniel. 2008. Global change effects on plant chemical defenses against insect herbivores. J. Integr. Plant Biol. 50: 1339-1354.

Blande, J. D., J. A. Pickett, and G. M. Poppy. 2004. Attack rate and success of the parasitoid Diaeretiella rapae on specialist and generalist feeding aphids. J. Chem. Ecol. 33: 1781-1795.

Bruce, T. J., L. J. Wadhams, and C. M. Woodcock. 2005. Insect host location: a volatile situation. Trends Plant Sci. 10: 269-274.

Butler, C. D., N. E., Beckage, and J. T., Trumble. 2009. Effects of terrestrial pollutants on insect parasitoids. Environ. Toxicol. Chem. 28: 1111-1119.

Ceulemans, R., I. Janssens, and M. Jach. 1999. Effects of $\mathrm{CO}_{2}$ enrichment on trees and forests: lessons to be learned in view of future ecosystem studies. Ann. Bot. 84: $577-590$.

Chen, F., F. Ge, and M. N. Parajulee. 2005. Impact of elevated $\mathrm{CO}_{2}$ on tri-trophic interactions of Gossypium hirsutum, Aphis gossypii, and Leis axyridis. Environ. Entomol. 34: $37-46$.

Chen, F., G. Wu, M. N. Parajulee, and F. Ge. 2007. Impact of elevated $\mathrm{CO}_{2}$ on the third trophic level: a predator Harmonia axyridis and a parasitoid Aphidius picipes. Biocontrol Sci. Technol. 17: 313-324.

Coviella, C. E., and J. T. Trumble. 1999. Effects of elevated atmospheric carbon dioxide on insect-plant interactions. Conserv. Biol. 13: 700-712.

DeLucia, E. H., P. D. Nabity, J. A. Zavala, and M. R. Berenbaum. 2012. Climate change: resetting plant-insect interactions. Plant Physiol. 160: 1677-1685.

Dicke, M. 2000. Chemical ecology of host-plant selection by herbivorous arthropods: a multitrophic perspective. Biochem. Syst. Ecol. 28: 601-617.

Fonseca, M. G., D. R. Santos, and A. M. Auad. 2014. Impact of different carbon dioxide concentrations in the olfactory response of Sipha flava (Hemiptera: Aphididae) and its Predators. J. Insect Behav. 27: 722-728.

Francis, F., S. Vandermoten, F. J. Verheggen, G. Lognay, and E. Haubruge. 2005a. Is the (E)- $\beta$-farnesene only volatile terpenoid in aphids? J. Appl. Entomol. 129: 6-11.

Francis, F., T. Martin, G. Lognay, and E. Haubruge. 2005b. Role of (E)-beta-farnesene in systematic aphid prey location by Episyrphus balteatus larvae (Diptera: Syrphidae). Eur. J. Entomol. 102: 431-436.

Gao, F., S. -R. Zhu, Y. C. Sun, L. Du, M. N. Parajulee, L. Kang, and F. Ge. 2008. Interactive effects of elevated $\mathrm{CO}_{2}$ and cotton cultivar on tri-trophic interaction of Gossypium hirsutum, Aphis gossyppii, and Propylaea japonica. Environ. Entomol. 37: 29-37.

Gao, F., F. Chen, and F. Ge. 2010. Elevated $\mathrm{CO}_{2}$ lessens predation of Chrysopa sinica on Aphis gossypii. Entomol. Exp. Appl. 135: 135-140.

Gate, I., S. McNeill, and M. Ashmore. 1995. Effects of air pollution on the searching behaviour of an insect parasitoid. Water Air Soil Pollut. 85: 1425-1430. 
Guerenstein, P. G., and J. G. Hildebrand. 2008. Roles and effects of environmental carbon dioxide in insect life. Ann. Rev. Entomol. 53: 161-178.

Hartley, S. E., C. G. Jones, G. C. Couper, and T. H. Jones. 2000. Biosynthesis of plant phenolic compounds in elevated atmospheric $\mathrm{CO}_{2}$. Glob. Change Biol. 6: 497-506.

Harvey, J., S. van Nouhuys, and A. Biere. 2005. Effects of quantitative variation in allelochemicals in Plantago lanceolata on development of a generalist and a specialist herbivore and their endoparasitoids. J. Chem. Ecol. 31: 287-302.

Heliövaara, K., and R. Väisänen. 1986. Parasitization in Petrova resinella (Lepidoptera, Tortricidae) galls in relation to industrial air pollutants. Silva Fenn. 20: 233-236.

Hentley, W. T., R. S. Hails, S. N. Johnson, T. H. Jones, and A. J. Vanbergen. 2014a. Top-down control by Harmonia axyridis mitigates the impact of elevated atmospheric $\mathrm{CO} 2$ on a plant-aphid interaction. Agric. For. Entomol. 16: 350-358.

Hentley, W. T., A. J. Vanbergen, R. S. Hails, T. H. Jones, and S. N. Johnson. 2014b. Elevated atmospheric $\mathrm{CO}_{2}$ impairs aphid escape responses to predators and conspecific alarm signals. J. Chem. Ecol. 40: 1104-1114.

Holopainen, J. K. 2002. Aphid response to elevated ozone and $\mathrm{CO}_{2}$. Entomol. Exp. Appl. 104: 137-142.

Holopainen, J. K., S. Himanen, and G. Poppy. 2013. Climate change and its effects on the chemical ecology of insect parasitoids, 168-190. In E. Wajnberg and S. Colazza (eds.), Chemical Ecology of Insect Parasitoids. John Wiley and Sons, Oxford, United Kingdom.

Holton, M. K., R. L. Lindroth, and E. V. Nordheim. 2003. Foliar quality influences tree-herbivore-parasitoid interactions: effects of elevated $\mathrm{CO}_{2}, \mathrm{O}_{3}$, and plant genotype. Oecologia 137: 233-244.

(IPCC) Intergovernmental Panel on Climate Change. 2013. Climate Change 2013-The physical science Basis. Contribution of working group I to the fifth assessment report of the IPCC. Cambridge University press, Cambridge, United Kingdom and New York, NY.

Jackson, G. E. 1995. The effect of ozone, nitrogen dioxide or nitric oxide fumigation of cereals on the rose grain aphid Metopolophium dirhodum. Agric. Ecosyst. Environ. 54: $187-194$.

Jones, C. G. and J. S. Coleman. 1988. Plant stress and insect behavior: Cottonwood, ozone and the feeding and oviposition preference of a beetle. Oecologia 76:51-56.

Karnosky, D. F., J. M. Skelly, K. E. Percy, and A. H. Chappelka. 2007. Perspectives regarding 50 years of research on effects of tropospheric ozone air pollution on US forests. Environ. Pollut. 147: 489-506.

Klaiber, J., A. J. Najar-Rodriguez, E. Dialer, and S. Dorn. 2013. Elevated carbon dioxide impairs the performance of a specialized parasitoid of an aphid host feeding on Brassica plants. Biol. Control 66: 49-55.

Lindroth, R. L. 2010. Impacts of elevated atmospheric $\mathrm{CO}_{2}$ and $\mathrm{O}_{3}$ on forests: phytochemistry, trophic interactions, and ecosystem dynamics. J. Chem. Ecol. 36: 2-21.

Meleux, F., F. Solmon, and F. Giorgi. 2007. Increase in summer European ozone amounts due to climate change. Atmos. Environ. 41: 7577-7587.

Mondor, E. B., M. N. Tremblay, C. S. Awmack, and R. L. Lindroth. 2004. Divergent pheromone-mediated insect behavior under global atmospheric change. Glob. Change Biol. 10: 1820-1824.

Percy, K. E., C. S. Awmack, R. L. Lindroth, M. E. Kubiske, B. J. Kopper, J. G. Isebrands, K. S. Pregitzer, G. R. Hendrey, R. E. Dickson, D. R. Zak, et al. 2002. Altered performance of forest pests under atmospheres enriched by $\mathrm{CO}_{2}$ and $\mathrm{O}_{3}$. Nature 420: 403-408.
Pickett, J. A., and R. T. Glinwood. 2007. Chemical ecology, 235-260. In H.F. Van Emden and R. Harrington (eds.), Aphids as crop pests. CABI, Wallingford, United Kingdom.

Pinto, D. M., J. M. Blande, R. Nykänen, W. -X. Dong, A. -M. Nerg, and J. K. Holopainen. 2007a. Ozone degrades common herbivore-induced plant volatiles: does this affect herbivore prey location by predators and parasitoids? J. Chem. Ecol. 33: 683-694.

Pinto, D. M., A.M. Nerg, and J. K. Holopainen. 2007b. The role of ozone-reactive compounds, terpenes, and green leaf volatiles (GLVs), in the orientation of Cotesia plutellae. J. Chem. Ecol. 33: 2218-2228.

Pinto, D. M., S. J. Himanen, A. Nisinen, A.M. Nerg, and J. K. Holopainen. 2008. Host location behavior of Cotesia plutellae Kurdjumov (Hymenoptera: Braconidae) in ambient and moderately elevated ozone in field conditions. Environ. Pollut. 156: 227-231.

Pinto, D. M., J. M. Blande, S. R. Souza, A.M. Nerg, and J. K. Holopainen. 2010. Plant volatile organic compounds (VOCs) in ozone $\left(\mathrm{O}_{3}\right)$ polluted atmospheres: the ecological effects. J. Chem. Ecol. 36: 22-34.

Roth, S. K., and R. L. Lindroth. 1995. Elevated atmospheric $\mathrm{CO}_{2}$ : effects on phytochemistry, insect performance and insect parasitoid interactions. Glob. Change Biol. 1: 173-182.

Roth S. K., C. Knorr and R. L. Lindroth. 1997. Dietary phenolics affect performance of the gypsy moth (Lepidoptera: Lymantriidae) and its parasitoid Cotesia melanoscela (Hymenoptera: Braconidae). Environ. Entomol. 26: 668-671.

Stacey, D. A., and M. D. Fellowes. 2002. Influence of elevated $\mathrm{CO}_{2}$ on interspecific interactions at higher trophic levels. Glob. Change Biol. 8: 668-678.

Stiling, P., and T. Cornelissen. 2007. How does elevated carbon dioxide $\left(\mathrm{CO}_{2}\right)$ affect plant-herbivore interactions? a field experiment and meta-analysis of $\mathrm{CO}_{2}$-mediated changes on plant chemistry and herbivore performance. Glob. Change Biol. 13: 1823-1842.

Stiling, P., A. M. Rossi, B. Hungate, et al. 1999. Decreased leaf-miner abundance in elevated $\mathrm{CO}_{2}$ : reduced leaf quality and increased parasitoid attack. Ecol. Appl. 9: 240-244.

Sun, Y. C., J. Su, and F. Ge. 2010. Elevated $\mathrm{CO}_{2}$ reduces the response of Sitobion avenae (Homoptera: Aphididae) to alarm pheromone. Agric. Ecosyst. Environ. 135: 140-147.

Sun, Y. C., L. Feng, F. Gao, and F. Ge. 2011. Effects of elevated $\mathrm{CO}_{2}$ and plant genotype on interactions among cotton, aphids and parasitoids. Insect Sci. 18: 451-461.

Vandermoten, S., M. C. Mescher, F. Francis, E. Haubruge, and F. J. Verheggen. 2012. Aphid alarm pheromone: an overview of current knowledge on biosynthesis and functions. Insect Biochem. Mol. 42: 155-163.

Verheggen, F., Q. Fagel, S. Heuskin, G. Lognay, F. Francis, and E. Haubruge. 2007. Electrophysiological and behavioral responses of the multicolored Asian lady beetle, Harmonia axyridis Pallas, to sesquiterpene semiochemicals. J. Chem. Ecol. 33: 2148-2155.

Verheggen, F., L. Arnaud, S. Bartam, M. Gohy, and E. Haubruge. 2008. Aphid and plant volatiles induce oviposition in an aphidophagous hoverfly. J. Chem. Ecol. 34: 301-307.

Vet, L., and M. Dicke. 1992. Ecology of infochemical by natural enemies in a tritrophic contex. Annu. Rev. Entomol. 37: 141-172

Villemant, C. 1981. Influence de la pollution atmosphérique sur les populations d'aphides du pin sylvestre en forêt de Roumare (Seine-Maritime). Environ. Pollut. A 24: 245-262.

Vuorinen, T., A. -M. Nerg, A. M. Ibrahim, G. V. Reddy, and J. K. Holopainen. 2004. Emission of Plutella xylostellainduced compounds from cabbages grown at elevated $\mathrm{CO}_{2}$ 
and orientation behavior of the natural enemies. Plant Physiol. 135: 1984-1992.

Walker, M., and T. H. Jones. 2001. Relative roles of top-down and bottom-up forces in terrestrial tritrophic plant-insect herbivore-natural enemy systems. Oikos 93: 177-187.

Wang, G., X. X. Wang, Y. C. Sun, and F. Ge. 2014. Impacts of elevated $\mathrm{CO}_{2}$ on Bemisia tabaci infesting Bt cotton and its parasitoid Encarsia formosa. Entomol. Exp. Appl. 152: 228-237.

Webster, B. 2012. The role of olfaction in aphid host location. Physiol. Entomol. 37: 10-18.

Webster, B., T. Bruce, J. A. Pickett, and J. Hardie. 2008. Olfactory recognition of host plants in the absence of hostspecific volatile compounds. Commun. Integr. Biol., 1: 167-169.

Whittaker, J. B. 1999. Impacts and responses at population level of herbivorous insects to elevated $\mathrm{CO}_{2}$. Eur. J. Entomol. 96: 149-156.

Yin, J., Y. C. Sun, G. Wu, M. N. Parajulee, and F. Ge. 2009. No effects of elevated $\mathrm{CO}_{2}$ on the population relationship between cotton bollworm, Helicoverpa armigera Hübner (Lepidoptera: Noctuidae), and its parasitoid, Microplitis mediator Haliday (Hymenoptera: Braconidae). Agric. Ecosyst. Environ. 132: 267-275.

Yin, J., Y. C. Sun, and F. Ge. 2014. Reduced plant nutrition under elevated $\mathrm{CO}_{2}$ depresses the immunocompetence of cotton bollworm against its endoparasite. Sci. Rep. 4: 4538 .

Zvereva, E. L., and M. V. Kozlov. 2000. Effects of air pollution on natural enemies of the leaf beetle Melasoma lapponica. J. Appl. Ecol. 37: 298-308.

Zvereva, E. L., and M. V. Kozlov. 2006. Top-down effects on population dynamics of Eriocrania miners (Lepidoptera) under pollution impact: does an enemy-free space exist? Oikos 115: 413-426.

Zvereva, E. L., and M. V. Kozlov. 2010. Responses of terrestrial arthropods to air pollution: a meta-analysis. Environ. Sci. Pollut. R. Int. 17: 297-311.

Received 28 May 2014; accepted 13 November 2014. 